\title{
The Role of Teaching Goals and Instructional Technology Perceptions in Faculty Members' Technology Use
}

\author{
Trang Phan \\ California State University Fresno, Fresno, CA, USA \\ ORCID: 0000-0003-0697-8272 \\ Mary Paul \\ California State University Fresno, Fresno, CA, USA \\ ORCID: 0000-0001-6758-0570 \\ Meina Zhu \\ Wayne State University, Detroit, MI, USA \\ ORCID: 0000-0002-5901-9924
}

Received: 11 Nov 2020

Accepted: 3 Feb 2021

\begin{abstract}
This study portrays profile uses of technology in the classroom by faculty at a school of education at a university in Central California ( $N=47)$. First, it describes their professional uses of certain technology on a frequency scale. Second, it reports the effects of faculty's teaching philosophy and perceptions of instructional technology (IT) in their teaching practice with regards to use of technology. This study employed quantitative data analysis. The findings indicate that faculty's teaching goals and perception of the learning environment play an important role in determining their uses of technology. Third, it reveals faculty's motivation and challenges to use certain technological tools in their teaching. Specifically, the participants reported high levels of motivation for using various new technologies, minimal challenges to IT use in their classroom and their actual uses of such technology being unknown. Given the faculty's high motivation (or absence of barriers) of using various innovative technology, one of the suggestions for future professional development programs is to offer training which moves beyond understanding how to use technology, and addresses the effectiveness and efficiency of teaching with technology.
\end{abstract}

Keywords: technological practice, perceptions, teaching philosophy, instructional technology, professional development

\section{INTRODUCTION}

Monumental changes have occurred over the past thirty to fifty years as to how college instructors teach students, engage students, and assess the learning experience (Nordquist \& Laing, 2015). The research is fairly extensive as to technology's role in student success and student learning outcomes (Byers, Imms, \& Hartnell-Young, 2014). Institutions offer broad ranges of professional development (PD) in order to promote course redesign and understand faculty's perspective of teaching with technology (Eliason \& Holmes, 2012). Educational technology shifts the learning environment where instructors can facilitate learning rather than delivering course content, a passive and traditional teaching format (McWilliam, Sweet, \& Blythe, 2013; Nordquist \& Lang, 2015; Paavlova \& Hakkarainen, 2009). However, faculty perception of the usefulness of technology plays a role in the course redesign process. Institutions would be well-served to explore faculty beliefs about the advantages and disadvantages of a technology-infused curriculum. 
Universities are unique in their organizational structure; it is a lateral organization structure which is decentralized (Bolman \& Deal, 2013). As such, professors have control over how their courses will be managed and delivered (Dovros \& Makrakis, 2012). So, as one considers the process of course redesign, the question becomes one of value: the perceived value of technology to the instructor (Ferreira, 2012). Seminoff and Wepner (1997) conducted a study that considered the value and motivation criteria for faculty adoption of technology-based projects. Their findings indicate that value should begin at the institutional level, suggesting innovative teaching practices become part of the tenure and promotion process. While valuing the contribution of teaching with technology within the profession may promote course redesign, Wood, Mueller, Willoughby, Specht, and Deyoung (2005) suggest that instructors' knowledge, skills and attitudes play a significant role in the adoption process. The findings of Wood et al. (2005) suggest that instructor comfort and experience with technology was the biggest predictor of instructor use of teaching with technology.

Without trying to better understand how and why faculty adopt educational technology, institutions are simply grasping for solutions to improve student success and faculty success (Keenwe, Kidd, \& Kyei-Blandson, 2009; Waxman, Wu, Michko, \& Lin, 2013). Research found, in general, faculty resisted the use of technology for teaching purposes (Keenwe et al., 2009; Tiwari, 2020). There is no clear pathway toward course redesign. Simply creating the infrastructure for IT use is not an adequate incentive (Hagenson \& Castle, 2003). A clearer understanding of the process and motivation for faculty adoption promotes an opportunity for more clearly defined assessment (Keenwe et al., 2009). As budgets become leaner, and technology becomes a near requirement for teaching and learning, universities will need to answer the questions as to why faculty are adopting technology and how it is promoting student success (Kavanagh \& Ashkanasy, 2006; Macfadyen \& Dawson, 2012). The answers to these questions begin with faculty perceptions.

There are two leading factors that influence the use of technology adoption and instructional methods: instructor knowledge and skills of the technology (Staub \& Stern, 2002), and their attitude and perception of value of the teaching tools (Marbán \& Mulenga, 2019; van den Berg, 2002). Ross, Hogaboam-Gray, and Hannay (2001) suggest that these factors influence student perception of the learning process. Student perception of the value of the teaching environment is based on how they assess the importance of the learning activity and the resulting learning outcome (Buil, Catalan, \& Martine, 2016; Pekrun, Goetz, Frenzel, Barchfield, \& Perry, 2011). If an instructor is confident and comfortable using technology in the learning environment, that confidence extends to teaching efficacy; the practice will improve student learning (Ross et al., 2001). Educators with higher levels of teaching efficacy are more likely to experiment with new technologies, especially innovative practices that create a more student-centered and student-controlled learning environment. This is the premise of Student-centered Learning (SCL) offered by Means (1994). The increased student engagement initiated by the use of technology requires educators to realign their teaching and student learning outcomes (Keenwe et al., 2009). Instructors who are comfortable using technology and understand how the pedagogy improves student learning, believe they will overcome barriers that might exist in the adoption process (Czerniak, \& Lumpe, 1996; Ross, 1992; Ross et al., 2001). This study was guided by the following research questions:

1. To what degree were faculty's teaching practices in regards to uses of technology affected by their perception of the teaching and learning process?

2. To what degree were faculty's teaching practices in regards to uses of technology hindered or affected by their perceptions of IT?

3. What were the faculty's motivations and barriers of using technology?

\section{THEORETICAL FRAMEWORK}

The theoretical framework adopted in this study is $\mathrm{SCL}$, which refers to the situation that students play an active role in their learning and being responsible for organizing, analyzing, and synthesizing content (Means, 1994). Four years later, Means and Olson (1997) defined student-centered learning as using technology to 
"promote student learning through collaborative involvement in authentic, challenging, multidisciplinary tasks by providing realistic complex environments for student inquiry, furnishing information and tools to support investigation, and linking classrooms for joint investigations" (p. 9). With faculty support, students can control their learning, determine their learning goals, select their learning strategies, and monitor the learning process (Hannafin, Hannafin, \& Gabbitas, 2009; Hannafin et al., 2014; Hannafin, Land, \& Oliver, 1999). In SCL, students have an opportunity to investigate complex problems by leveraging different available resources, come up with different solutions for addressing problems, and collaboratively decide and present final solutions to these problems (Hannafin, Hill, \& Land, 1997). Faculty design curriculum to facilitate engagement rather than deliver content. SCL emphasizes authentic experiences, encourages active learning, and results in the creation of new products.

The theoretical foundation of SCL is constructivism, which indicates that learning should be constructed by and for students (Duffy \& Jonassen, 1992; Jonassen, 1992). Social constructivist, Vygotsky (1980), considered learning as a social interaction process in which learners interact with the surrounding environment. He advocated that the instructional environment should provide opportunities for learners to explore concepts, discuss, and negotiate meanings with peers. Later, research thought that SCL should provide a curriculum which motivates students to participate in challenging and authentic activities to solve problems (Brush \& Saye, 2000). These learning environments should give students an opportunity to work collaboratively on different solutions for addressing problems, and try different solutions within an authentic environment (Bednar et al., 1992; Brown, Collins, \& Duguid, 1989; Duffy \& Jonassen, 1992). Meanwhile, Lee and Hannafin (2016) argued that SCL is a complex learning process in which students need support regarding the motivational, cognitive, and social aspects. A common misunderstanding about SCL is that students should learn independently without external support (Hannafin et al., 2014). On the contrary, students need instructors' guidance through the learning process.

Two primary reasons for using SCL in class were categorized: (1) making learning enjoyable, and (2) improving students' learning outcomes (Froyd, 2008). SCL emphasizes the importance of learners' prior experiences, highlighting individual needs, encouraging active participation, enhancing higher-order thinking, and promoting life-long learning (e.g., Bonk \& Cunningham, 1998; Brown et al., 1989). Specifically, studies have indicated that $\mathrm{SCL}$ has a positive influence on cultivating and developing higher-order skills such as critical thinking and problem solving (e.g., Alper, 1996; Gallagher \& Stepien, 1996). In addition, it was advocated as a means to increase academic performance (Hannafin \& Foshay, 2008; Mergendoller, Maxwell, \& Bellisimo, 2006), help students develop lifelong learning skills such as self-regulation and problem-solving (Bereiter \& Scardamalia, 2006), and increase information and communication technology skills (Kozma, 2003). The instructor role and responsibilities are significantly altered from a traditional lecture environment (Onurkan, Gulen, \& Ozer, 2017). Faculty are charged with preparing students for SCL and collaborative engagement (Doyle, 2008; Onurkan, Gulen, \& Ozer, 2017).

\section{Learning is a Process of Engagement}

Understanding that student engagement promotes more than simply active learning is a step toward innovative teaching. When students are motivated to engage with course content, their perceived selfefficacy improves (Bandura, 1977; Lee \& Reeve, 2012). Lee and Reeve (2012) posited the Self-determination theory (SDT), which suggests that students are motivated to learn when they believe they are able to master a specific learning goal. Instructors have the ability to establish learning objectives which increase student engagement, thus increase their self-efficacy. The design process should include opportunities for students to measure their achievement potential. Salas-Rueda (2018) looked beyond the design process, and considered the process of improving the teaching and learning environment based upon evolutions of quality: inspection, quality control, quality assurance, and total quality management. Specifically, their findings suggest that students value the quality of their education with technology-enhanced learning (SalasRueda, 2018). In essence, the author makes the assimilation of improving the teaching environment to improving customer satisfaction. 
The use of goal theories helps instructors understand student participation and improved goal competence (Ames \& Archer, 1988; Lee \& Reeve, 2012). Thus, knowledge of specific student engagement in a learning activity can promote a stronger sense of instructor self-efficacy to move onto more challenging goals (Conley \& French, 2014; Zimmerman, Bandura, \& Martinez-Pons, 1992). Students are constantly self-assessing what they believe can be achieved (Bandura, 1977). Faculty adoption of a curriculum design which can measure a student's level of self-assessment at any given time, establishes a more supportive learning environment. Instructors can engage students in specific tasks or quizzes with the use of technology allowing students to make the connection between content and their understanding (Cowie \& Bell, 1999). Intentional studentengagement activities scaffolded across a learning module or course topic, promotes self-directed learning (Lee \& Reeve, 2012).

\section{Faculty Use of Formative Assessment}

Sadler (1998) defines formative assessment as an intentional process to better understand student content knowledge based upon student feedback or response. Nicol, Macfarlane, and Dick (2006) posit that the use of formative assessment activities in higher education promotes a stronger agency over student learning; students become more independent learners. Nichols and Dawson (2012) looked specifically at the use of Classroom-based tests (CB) in relation to student understanding of specific topics lectures.

The use of CBs allows instructors to gauge student understanding and adjust learning activities accordingly (Fies \& Marshall, 2006; Nichols \& Dawson, 2012). Hawe (2007) studied the use of formative assessment among pre-service teachers. The study considered instructor use of assessment activities which were explicitly defined and implicitly embedded into the curriculum. The author suggested that assessment activities which were not clearly understood created a hidden curriculum for students to navigate, thus affecting student perception of the content assessment. The author concludes with Biggs (1999) findings that strategically embedded assessment activities which lead to purposeful instructor feedback creates a constructive teaching and learning environment. Assessment activities which offer students a clear understanding of instructor expectations, such as examples of exemplar work, encouraged students to selfassess (Hawe, 2007).

Kulasegaram and Rangachari (2018) studied the use of formative assessment strategies. They noted the use of in-class quizzes which prompted students to register facts or items that would eventually accumulate in summative assessment. The authors explained that this approach was useful for content competency; however, they explained that a more student-centered assessment process cultivates critical thinking skills. A student-centered assessment approach is more specific to the individual learning experience, thus enhancing the teacher-to-student relationship (Kulasegaram \& Rangachari, 2018). While not every student is going to respond to assessment questions in a classroom, the use of technology offers a platform for every student to demonstrate their level of understanding.

Boyle and Nicol (2003) acknowledged faculty concerns with the use of technology in large lecture classes. The authors studied the use of clickers to poll student understanding in the middle of a lecture. Their study explained instructors' fear that students would be engaging with their devices rather than focusing on the material being delivered (Boyle \& Nicol, 2003). Acknowledging faculty unease opens the conversation for improvement. Purposeful professional development aimed at understanding faculty perception of the use of technology may be a catalyst for better assessment practices, and a more student-centered pedagogy.

\section{Faculty's Adoption of Technology - Motivation and Barriers}

Contemporary teaching using digital tools requires educators to confront their beliefs and attitudes about learning the skills needed to engage students (Chiu \& Churchill, 2016; ChanLin, 2017; Mishra \& Koehler, 2006). Even if a teacher's pedagogical beliefs and attitudes toward technology suggest that computer integration would be a meaningful teaching approach, the teacher must believe that he or she is capable of implementing technology successfully in order to act on those beliefs (Mueller, Wood, Willoughby, Ross, \& Specht, 2008). Lai (2019) considered the specific integration of interactive whiteboards in the classroom. The authors stressed that the use of such technology should not be focused solely on the technology tool; but 
rather, on the instructor's perceived usefulness to enhance instruction. The authors explain that building a school culture which advocates the advantages of technology integration will benefit instructor adoption of technology (Lai, 2019).

Challenges arise as to how to design teaching activities and how to manage classroom settings. Technology competency and use by faculty in lecture-centered teaching environments is very different from those who teach in more interactive and collaborative classrooms, implementing social-learning theories (Moats, 2015). However, faculty are intrinsically motivated to adopt technology when it is perceived to improve teaching efficiency and potentially improve job performance (Davis, 1989; Yim, Moses, \& Azalia, 2018). Cheng and Yeh (2009) discusses the nature of intrinsic motivation and explains that people engage in new innovations and tasks because they experience feelings of pleasure, enjoyment, and interest.

Conversely, intrinsic motivation to continue a task may spontaneously end when confronted with barriers. Intrinsic motivation may be activated by a sense of comfort with a specific technology. Yim et al. (2018) considered the theory of psychological ownership of technology use, and suggested that instructors who have a feeling of ownership over a tool will have a favorable perception of its use. In other words, the sense of ownership or attachment to teaching with technology promotes a pathway toward ease of use and further innovation. Insorio (2021) looks specifically at the use of mobile technology in education, and explains that mobile learning is a sustainable and equitable learning tool in today's teaching environment. Students have access to and understanding of mobile devices (Insorio, 2021). Engaging students through this familiar medium is a student-centered approach to learning. The study acknowledged instructors' comfort level and ownership of mobile technology; however, teaching and designing curriculum around mobile applications was a barrier to implementation (Insorio, 2021).

\section{Student-led Discussion}

Student group discussion is a strategy to promote SCL. Discussion group practices can be implemented in the face-to-face classroom as well as virtually, using web-based technology (Brower, 2003). Researchers have stated that discussion can foster the construction of knowledge (Bridges, 1988). Students' thoughts might be challenged through discussion (Bond, 2001), which encourages them to share more background knowledge and thoughts. The discussion may help students collaboratively interpret meaning (Almasi, McKeown, \& Beck, 1996) and foster creativity (Almasi et al., 2004). In addition, group discussion could develop ownership of learning. Researchers found that the time spent on group discussion has positive influences on their perceptions of the content value (Almasi et al., 2004).

Moreover, Maloch (1999) highlighted the importance of using student-lead discussion. As Worthy and Beck (1995) stated, in student-led discussion, teachers' role shifted from controller to facilitator. Cheng, Kin, Pare, Dwayne, Collimore, and Steve (2011) suggest that virtual discussion forums enhance student-to-faculty interaction by creating a less intimidating social environment. Hulan (2010) investigated student-led and instructor-led discussion within reading groups and found that both methods have advantages. However, she noted that the advantages of using student-led discussion, which potentially offer learners a safe talk environment (Vygotsky, 1978). In student-led discussion, students feel less pressure of being judged by an instructor (Almasi et al., 1996; Leal, 1993). The open environment for sharing viewpoints promotes in-depth understanding of the learning content (Keefer, Zeitz, \& Resnick, 2000).

\section{METHODOLOGY}

This study adopted quantitative data collection and analysis methods, specifically correlational data analysis. Data in this study were collected from an online survey from 47 tenure-track faculty members.

\section{Data Sources}

Qualified participants for this study were tenure track faculty members coming from various programs (i.e., Curriculum and Instruction, Early Childhood, Multilingual Multicultural, Reading and Language Arts, Special Education, Liberal Studies, etc.) and taught courses at all levels at a university in Central California. Their 
insights and experience in using technology professionally in the classroom were foundational to findings of this study.

An online survey was developed based on literature reviews by the researchers. The online survey included ten questions regarding faculty's perception of technology and their uses in the teaching and learning environment. Specifically, the survey was constructed using the following themes: (1) Faculty's teaching records (i.e., Face-to-face vs. online or both), (2) faculty's participation in the university technology PD training (i.e., QOLT and/or DISCOVERe) , (3) faculty's professional and personal use of technology, (4) faculty's perception of technological use in the classroom, (5) Faculty's use of technology in the face-to-face and online classroom, and (6) faculty's motivation and challenges in using technology. Here is one item example: "How often do you use the following technologies?" The survey provided the researchers with comprehensive insights into faculty's perceptions and actual uses of technology in the classroom, as well as the motivation and challenges in doing so. The survey was conducted on Google Forms and distributed to all faculty members in the school of education using merge mail. Follow up emails were used to gain a higher response rate. The survey was open for two weeks. It took approximately 10 minutes for the participants to finish the survey. The survey was sent to 83 tenure-track and four adjunct faculty members in the school of education to collect quantitative data. Forty-seven faculty completed the survey.

\section{Reliability}

Most of the survey items (with the exception of the items about faculty's demographic information, their teaching records and their faculty's participation in the university technology PD training), were compiled via different sources including survey instruments from published journal articles. That is, most of them were tested for reliability. Multiple drafts of the survey were drafted prior to finalizing the one used in this study to help ensure content validity.

\section{Data Analysis}

This study adopted descriptive statistics and inferential statistics using SPSS to analyze survey data. First, the mean and standard deviation of the survey items were reported. Second, researchers conducted correlational analysis among different variables.

\section{FINDINGS}

This section discusses quantitative findings on the faculty's professional uses of technology in the classroom and how their uses of technology are affected by their teaching goals and perceptions of instructional technology. It also reports in-depth insights on the motivations and barriers in using technology for a representative number of faculty members.

\section{Descriptive Statistics}

There were 47 out of 84 faculty members (54\% response rate) responding to the survey questionnaire. Among the survey respondents, 27 reported teaching a face-to-face course (57.4\%), 15 taught both online and face-to-face courses (31.9\%), and two taught online courses only (4\%). These faculty members also participated in the technology-related professional development training program offered by the university. Specifically, 26 (55.3\%) participated in a campus-wide teaching with tablet initiative, and 13 (27.7\%) participated in an online teaching support program. Ten $(21 \%)$ faculty members participated in both programs.

\section{Faculty's Professional Uses of Technology}

The first question in the survey respectively addressed the professional uses of the technologies by the faculty members using a 0-4 Likert scale (i.e., 0: Never and 4: Daily). Table 1 shows the technologies used by most faculty members on a daily or weekly basis including 1) email $(97.8 \%), 2)$ Communication and collaboration tools (i.e., blogs, wiki, Google Docs, Microsoft Office Live) (72.3\%), 3) Media sharing sites (i.e., 
Table 1. Faculty's Professional Use of Technology

\begin{tabular}{|c|c|c|c|}
\hline \multirow{2}{*}{$\begin{array}{l}\text { Faculty's professional uses of technological tools } \\
\mathrm{N}=47(100 \%)\end{array}$} & \multicolumn{3}{|c|}{ Frequency of use (\%) } \\
\hline & $\begin{array}{l}\text { Daily/ } \\
\text { Weekly }\end{array}$ & Monthly & $\begin{array}{c}\text { Rarely/ } \\
\text { Never }\end{array}$ \\
\hline Email & 97.8 & 2.2 & 0 \\
\hline Communication and collaboration tools (i.e., blogs, wiki, Google Docs, Microsoft Office Live) & 72.3 & 17 & 10.6 \\
\hline Media sharing sites (i.e., YouTube, Flickr) & 68.1 & 12.8 & 19.1 \\
\hline Mp3 player (i.e., Blackberry, iPhone, Android) & 56.5 & 8.7 & 34.8 \\
\hline Voice over IP/ Web Conferencing (i.e., Skype, Adobe Connect, Google Chat, GoToMeeting) & 51.1 & 27.7 & 29.8 \\
\hline Social networking (i.e., Facebook, Myspace, LinkedIn, Twitter) & 36.2 & 4.3 & 59.6 \\
\hline Instant messaging (i.e., AIM, Google Chat) & 29.8 & 10.6 & 59.6 \\
\hline Multimedia editing software (i.e., iMovie, Final Cut, Premiere, Audacity, Flash, Camtasia) & 12.8 & 27.7 & 59.6 \\
\hline Remote Access (i.e., TeamViewer, GoToMyPC, LogMeln) & 6.4 & 10.6 & 83 \\
\hline RSS Aggregator/ Reader (i.e., Bloglines, Google Reader, Netvibes) & 4.2 & 4.3 & 91.5 \\
\hline Gaming or virtual worlds (i.e., WoW, Second Life) & 2.1 & 2.1 & 95.7 \\
\hline
\end{tabular}

YouTube, Flickr) (68.1\%), 4) Mp3 player (i.e., Blackberry, iPhone, Android) (56.5\%) and 5) Voice over IP/ Web Conferencing (i.e., Skype, Adobe Connect, Google Chat, GoToMeeting) (51.1\%). The technologies that they almost never used included 1) Gaming or virtual worlds (i.e., WoW, Second Life) (95.7\%), 2) RSS Aggregator/ Reader (i.e., Bloglines, Google Reader, Netvibes) (91.5\%), 3) Remote Access (i.e., TeamViewer, GoToMyPC, LogMeln) (83\%), 4) Multimedia editing software (i.e., iMovie, Final Cut, Premiere, Audacity, Flash, Camtasia) (59.6\%), and 5) Social networking (i.e., Facebook, Myspace, Linkedln, Twitter) and Instant messaging (i.e., AIM, Google Chat) (59.6\%).

\section{Faculty's Uses of Technology and their Perception of the Teaching and Learning Process}

This section presents the correlations between the faculty's uses of technology and their teaching goals (i.e., how their teaching goals and philosophy determined and were translated into their teaching practices in regards to using technology). In examining the faculty's teaching goals, one of the survey questions asked, "Please indicate how important each of the following teaching goals are to you", and the choices ranged from making lectures more interactive and engaging to providing connections with outside experts or community. Faculty participants were asked to rate their answer on the 1-5 Likert scale, "Don't know - very important" (1-5) for each of the items.

In order to understand their teaching practices, the following survey question was asked: "Do you use the following teaching methods in your course?" ranging from I lecture during the entire class period to I assign a short writing activity that is followed by at least 15 minutes of class discussion. Faculty participants were asked to rate their answer on the 1-4 Likert scale, "Not use - Currently use" (1-4) for each of the items.

Findings on the relationships between the faculty's teaching goals/philosophy and their teaching practices in regards to using technology are categorized into three themes as follows:

\section{Theme 1: Student engagement}

Faculty whose teaching philosophy had a great focus on student engagement tend to make their lecture more engaging and interactive. In fact, most of the effort was dedicated to building quality interaction between teacher-student and student-student. An example of this is that a great deal of their lecture time was used to recite or ask questions to check student understanding of the material, a form of formative assessment practices. Another indication of facilitating engagement and interaction between students and faculty is the engagement of online components in face-to-face courses. During the lecture, these faculty members would give a short, ungraded quiz to check their student understanding of the material. Yet, another technique used by these faculty members was the application of alternatives to traditional assessment methods for content comprehension to engage student learning. A few examples of this include 1) showing a film or video for the entire class period and elicit feedback from the students, and 2) leading a class discussion focused on a visual/audio stimulus by employing pictures, cartoons, graphics, or songs. 
Table 2. Faculty's Teaching Practice with regards to Technology and their Teaching Goals

\begin{tabular}{|c|c|c|c|c|c|c|}
\hline & $\begin{array}{c}\text { Interactive } \\
\text { / } \\
\text { engaging } \\
\text { lectures }\end{array}$ & $\begin{array}{c}\text { Adding } \\
\text { online } \\
\text { components } \\
\text { to face-to- } \\
\text { face courses }\end{array}$ & $\begin{array}{c}\text { Reinforcing } \\
\text { learning } \\
\text { outcomes }\end{array}$ & $\begin{array}{l}\text { Focusing } \\
\text { on real } \\
\text { world } \\
\text { problems }\end{array}$ & $\begin{array}{l}\text { Addressing } \\
\text { students' } \\
\text { diverse } \\
\text { learning } \\
\text { styles }\end{array}$ & $\begin{array}{c}\text { Using } \\
\text { alternatives } \\
\text { to traditional } \\
\text { assessment }\end{array}$ \\
\hline $\begin{array}{l}\text { TPr 2: Give a short, ungraded quiz to check } \\
\text { student comprehension of materials }\end{array}$ & & .011 & & & & \\
\hline $\begin{array}{l}\text { TPr 3: Show a film or video for the entire } \\
\text { class period }\end{array}$ & & & & -.018 & .018 & .020 \\
\hline $\begin{array}{l}\text { TPr 4: Assign a student-centered class } \\
\text { discussion }\end{array}$ & & & .015 & .040 & & \\
\hline $\begin{array}{l}\text { TPr 5: Have students complete a self- } \\
\text { assessment activity }\end{array}$ & & & .039 & & & \\
\hline $\begin{array}{l}\text { TPr 7: Recitate to check student } \\
\text { understanding of materials }\end{array}$ & .003 & & & & & \\
\hline $\begin{array}{l}\text { TPr 8: Lead a class discussion focused on a } \\
\text { visual/audio stimulus }\end{array}$ & & & & & .015 & .036 \\
\hline $\begin{array}{l}\text { TPr 10: Assign short follow-up writing } \\
\text { activities after class discussions }\end{array}$ & & & & & .033 & \\
\hline
\end{tabular}

\section{Theme 2: Reinforcement of learning outcomes}

On the other hand, faculty whose teaching philosophy focused on reinforcing student learning outcomes would tend to count on student self-reflection as a learning process. An example of this was assigning student-led class discussion by having them develop the questions and lead class discussions as facilitators. These faculty also had students complete a self-assessment activity including questionnaires about their beliefs, values and behaviors. The instructors who possessed these teaching goals also focused on directing their students towards real-world problems or tasks, and the aforementioned student-centered approach was applied. However, regarding real world problems, these instructors did not rely on videos for discussion; rather, they relied more heavily on engaging students in social interactions.

\section{Theme 3: Multi-modal/innovative practices}

Faculty whose teaching philosophy focused on creating multi-modal and innovative practices paid great attention to addressing student's diverse learning styles. These instructors employed alternatives to traditional assessment methods for content comprehension and to engage student learning. A number of teaching techniques applied in this case included 1) the employment of films or videos for the entire class period and eliciting of student's comprehensive feedback thereafter, 2 ) leading a class discussion focused on a visual/audio stimulus by employing pictures, cartoons, graphics, or songs, or 3 ) assigning short writing activities followed by class discussion.

\section{Faculty's Perceptions of Instructional Technology and their Teaching Practices in regards to Uses of Technology}

This section presents the correlations between the faculty's teaching practices and their perceptions of using instructional technology (IT) in teaching. In other words, how their perceptions about the use and purpose of IT determined their actual use of technology in their daily teaching practices. The corresponding survey question asked "Please indicate if you agree or disagree with the following statements about the use of instructional technologies," ranging from mindfully selecting and using appropriate technological tools that are particularly suited to course learning outcomes to being generally uncomfortable with new technologies. Faculty participants were asked to rate their answer on a 0-4 Likert scale, "Strongly disagree - strongly agree" $(0-4)$ scale on each of the items. 
Table 3. Faculty's Perceptions of Instructional Technology and their Uses of Technology in Teaching

\begin{tabular}{|c|c|c|c|}
\hline & $\begin{array}{c}\text { Achievement } \\
\text { and } \\
\text { retention }\end{array}$ & $\begin{array}{c}\text { Use } \\
\text { little/no } \\
\text { technology }\end{array}$ & $\begin{array}{c}\text { Uncomfortable } \\
\text { with new } \\
\text { technologies }\end{array}$ \\
\hline Teaching Practice 1: Lecture during the entire class period & & .012 & \\
\hline Teaching Practice 3: I show a film or video for the entire class period & & & .040 \\
\hline Teaching Practice 5: Have students complete a self-assessment activity & & .036 & \\
\hline Teaching Practice 7: Recitate to check student understanding of materials & & .026 & \\
\hline $\begin{array}{l}\text { Teaching Practice 8: Lead a class discussion focused on a visual/audio } \\
\text { stimulus }\end{array}$ & .015 & & \\
\hline
\end{tabular}

Table 4. Faculty's motivation in using technology

\begin{tabular}{|c|c|c|c|c|}
\hline$N=47$ & $\begin{array}{c}\text { Large } \\
\text { degree } \\
(\%)\end{array}$ & $\begin{array}{c}\text { Moderate } \\
\text { degree } \\
(\%)\end{array}$ & $\begin{array}{c}\text { Small } \\
\text { degree } \\
(\%)\end{array}$ & $\begin{array}{c}\text { Not at all/Not } \\
\text { applicable } \\
(\%)\end{array}$ \\
\hline Facilitate communication among students and instructors & 83 & 17 & 0 & 0 \\
\hline Facilitate students' access to course materials & 80.9 & 14.9 & 4.3 & 0 \\
\hline Enhance my ability to teach my materials & 78.7 & 14.9 & 6.4 & 0 \\
\hline Address different learning styles and needs & 72.3 & 23.4 & 4.3 & 0 \\
\hline Save time & 61.7 & 23.4 & 10.6 & 4.3 \\
\hline Enhance the quality work from students & 59.6 & 29.8 & 10.6 & 0 \\
\hline Reach students who can't come to campus & 59.6 & 21.3 & 6.4 & 12.8 \\
\hline Reduce cost education for students & 53.2 & 29.8 & 14.9 & 2.1 \\
\hline Expose students to the technology needed for future employment & 53.2 & 23.4 & 23.4 & 0 \\
\hline Respond to expectation of students for technology in their courses & 46.8 & 34 & 14.9 & 4.3 \\
\hline Personal enjoyment & 40.4 & 27.7 & 23.4 & 8.5 \\
\hline Manage courses with large enrollments & 27.7 & 31.9 & 17 & 23.4 \\
\hline Grants or awards & 12.8 & 12.8 & 17 & 57.4 \\
\hline Recognition from my peers & 6.4 & 8.5 & 17 & 68.1 \\
\hline
\end{tabular}

Table 3 shows a number of statistically significant differences between the faculty's uses of technology in their daily teaching practice and their perceptions of IT. Specifically, faculty whose focus was on using technologies to increase student achievement and retention (IT perc. 2) tended to employ student selfassessment activities and formative assessment activities following shorter lectures. An example would be leading a class discussion focused on a visual/audio stimulus by using picture, cartoon, graph, or song (Teaching Practice 8) $(p=.015)$. On the other hand, faculty who normally used little or no technology (IT perc. 3 ) in their course tended to lecture the entire time in the class (Teaching Practice 1$)(p=.012)$. However, they tended to be more concerned with the students' self-assessment of their beliefs, values, behaviors and collected the information through a survey questionnaire (Teaching Practice 5$)(p=.036)$ or devoted their lecture time to recitation or asking questions to check student understanding of material (Teaching Practice 7) $(p=.026)$. Faculty who were generally uncomfortable with new technologies (IT perc. 7) tended to show a film or video for the entire class period (Teaching Practice 3) $(p=.040)$.

\section{Faculty's Motivation and Barriers in Using Technology}

In examining faculty's perceived motivation and barriers in using technology, the quantitative results generated from the survey Likert-style question 19 "To what degree does each of the following motivate you to use IT in your teaching?" in which "Large degree" was scaled as 4 and "Not at all" or "Not applicable" were termed 1 and 0 respectively. The results are quantitatively summarized in Table 4.

Given the survey results, we found that the top six intrinsic motivation for faculty to use instructional technology (IT) in their teaching were: 1) Facilitate communication among students and instructors (83\%); 2) Facilitate students access to course materials (80.9\%); 3) Enhance my ability to teach my materials (78.7\%); 4) Address different learning styles and needs (72.3\%), and 5) Save time (61.7\%). We also found to a much 
Table 5. Faculty's barriers in using technology

\begin{tabular}{lcccc}
\hline N=47 & $\begin{array}{c}\text { Large } \\
\text { degree } \\
(\%)\end{array}$ & $\begin{array}{c}\text { Moderate } \\
\text { degree } \\
(\%)\end{array}$ & $\begin{array}{c}\text { Small } \\
\text { degree } \\
(\%)\end{array}$ & $\begin{array}{c}\text { Not at all/Not } \\
\text { applicable } \\
(\%)\end{array}$ \\
\hline Manage courses with large enrollments & 6.4 & 12.8 & 19.1 & 61.7 \\
Enhance my ability to teach my materials & 2.1 & 8.5 & 23.4 & 66 \\
Address different learning styles and needs & 4.3 & 10.6 & 27.7 & 57.4 \\
Facilitate communication among students and instructors & 4.3 & 6.4 & 19.1 & 70.2 \\
Facilitate students' access to course materials & 4.3 & 8.5 & 14.9 & 72.3 \\
Save time & 6.4 & 8.5 & 36.2 & 48.9 \\
Enhance the quality work from students & 2.1 & 6.4 & 38.3 & 53.2 \\
Respond to expectation of students for technology in their courses & 0 & 12.8 & 29.8 & 57.4 \\
Reach students who can't come to campus & 4.3 & 8.5 & 17 & 70.2 \\
Reduce cost education for students & 4.3 & 4.3 & 21.3 & 70.2 \\
Expose students to the technology needed for future employment & 2.1 & 4.3 & 21.3 & 72.3 \\
Recognition from my peers & 2.1 & 0 & 12.8 & 85.1 \\
Grants or awards & 2.1 & 2.1 & 12.8 & 83 \\
Personal enjoyment & 2.1 & 6.4 & 12.8 & 78.7 \\
\hline
\end{tabular}

lesser extent that these faculty members will use IT for extrinsic purposes such as "Grants or awards" (12.8\%) or "Recognition from peers" (6.4\%).

For the second part of RQ3, we examined the faculty's barriers in using instructional technology with the survey Likert-style question 20 "To what degree does each of the following acts as a barrier or challenge to your use of IT in your teaching?" Similarly, "Large degree" was scaled as 4 and "Not at all" or "Not applicable" were termed 1 and 0 respectively. The results are quantitatively summarized in Table 5.

Given the survey results, we found that on a large degree, most faculty members did not seem to encounter any major challenges in using IT in their teaching. In fact, most faculty reported having no barriers at all in using technology for their instructional purposes.

\section{DISCUSSION}

The findings show some relatively strong correlations between faculty's uses of technology as part of their teaching practices and their teaching philosophy, as well as their actual implementation/adoption.

\section{Faculty's Uses of Technology and their Teaching Philosophy}

Specifically, faculty whose teaching philosophy focused on reinforcing student learning outcomes tend to have students delve into content comprehension and collaborate with their peers to construct meaning. Faculty assigned student-led class discussion by having them develop the questions and lead class discussions. According to Bridges (1988), this could foster the construction of knowledge (Bridges, 1988) and encourage them to think more, share more and collaborate with the group to construct meaning (Almasi, McKeown, \& Beck, 1996).

Even though this may present challenges to the students (Bond, 2001) at first, it fosters their development of creativity and sense of ownership (Almasi et al., 2004) as they were working together in depth on a topic. The fact that the instructors shifted their role to a facilitator (Worthy \& Beck, 1995) instead of directly participating in the discussion has offered students a stress-free discussion environment (i.e., they could express their thoughts and ideas without worrying about being judged) (Almasi et al., 1996; Leal, 1993). This open environment for sharing information and points of view has promoted deep learning and contentcomprehension among the students (Keefer, Zeitz, \& Resnick, 2000).

On a different note, faculty whose teaching philosophy focused on addressing student's diverse learning styles chose to engage students with alternative assessment methods for content comprehension. Instructors assess student evaluation of the learning which influences their own value of the teaching 
technology (Ferreira, 2012). These faculty, while lacking a sense of familiarity and ease of use of technology tools, begin to innovate ways to engage students such as the use of digital questionnaires.

Asking students to reflect on the learning process and begin a discussion regarding their perceptions of its value, establishes student voice (Hulan, 2010). Teaching moves beyond lecturing course content toward engaging students to facilitate content. Contemporary learners are familiar with educational technology; they are motivated to excel when they can engage with content (Lee \& Reeve, 2012). This engagement process becomes beneficial to both students and faculty. When students find value in the learning process, instructors' teaching efficacy improves (Ross et al., 2001).

\section{Faculty's Perceptions of IT and their Teaching}

The findings from this study suggest that faculty see few if any barriers to using technology in teaching. They also suggest that instructors are motivated to use the technology they are most comfortable with. However, establishing and expanding that comfort level is a key component to adoption. Faculty may want to be more innovative, but motivational factors can hinder the adoption process (Mueller, Wood, Willoughby, Ross, \& Specht, 2008). The research suggests that there exist two main paths toward redesigning a course to integrate technology: ease of use and value of the technology tools by the educator (Staub \& Stern, 2002).

A passive lecture environment relies on content delivery rather than content creation or engagement. These faculty may have a fear of how to manage a classroom where students are connected to their devices (Boyle \& Nicol, 2003). In addition, these faculty may find little value in using technology in the classroom. University instructors are tasked with designing, delivering, and assessing course content. If these educators do not envision a more efficient mode of teaching, or a benefit to their overall job performance, there is a lack of motivation to redesign (Davis, 1989; Yim, Moses, \& Azalia, 2018).

The instructors in this study who perceive value in teaching with technology adopt innovative design fairly seamlessly: their use of technology was a natural part of their content delivery, and they acted independently to continue to innovate. These faculty may have a sense of ownership over their innovative practices; thus, they choose to navigate their own technology adoption (Yim et al., 2018). They begin to naturally integrate technology tools into their curriculum while at the same time, they switch their focus to student reflection of their understanding. Technology-savvy instructors understand that the use of assessment tools improves student learning by helping them make the connection between the lecture material and content understanding (Cowie \& Bell, 1999). The activities become more student-centered as to student perceptions of learning, which leads to improved student self-efficacy (Bandura, 1977).

\section{Limitations and Implications for Future Research}

There are several limitations of this study. First, the participants of this study were limited to 47 faculty from a school of education. The study finding may not represent the perceptions of faculty from other subject backgrounds. Researchers of this study are going to expand the research in diverse subjects in the follow-up studies. This study could be replicated in diverse schools to identify whether the subject background of faculty influences their technology use. Second, the two data collection methods were used: survey and focus group. In the future, in-depth interviews with individual faculty will help gather each independent faculty's perceptions and actual use of technology. Finally, due to the COVID-19, faculty members were forced to move to online/remote teaching in spring 2020. It would be interesting to examine faculty's perception and behavior changes regarding technology use.

\section{CONCLUSION}

The faculty in this study found very few barriers to teaching with IT. The survey results indicated, for the most part, that IT barriers were "not applicable." The lack of perceived barriers may be the result of finding value in technology and finding technological tools to be useful, and/or teaching with technology comes naturally with very little effort. In other words, technology was not considered an obstacle in the learning environment. However, it is important to note that acknowledging minimal challenges to IT use, does not equate to actually 
using innovative technology. It may be that university faculty are trying to strike a balance between supporting student achievement while maintaining a teaching practice that is efficient and effective. Faculty at the college of education demonstrated a high level of motivation for using various new technologies in their classroom, yet the actual implementation was less than innovative and somewhat minimal. The fact that there is a gap between faculty's motivation (or absence of barriers) of using such innovative technology and the actual uses, raises a question of what may have prohibited them from doing so. This study suggests that professional development and curriculum design initiatives move beyond introducing technology best practices, and instead focus on the impact of technology in both the teaching and learning capacity. Student success is a core value for higher education; however, faculty success must coincide.

Author contributions: All authors were involved in concept, design, collection of data, interpretation, writing, and critically revising the article. All authors approve final version of the article.

Funding: The authors received no financial support for the research and/or authorship of this article.

Declaration of interest: Authors declare no competing interest.

Data availability: Data generated or analysed during this study are available from the authors on request.

\section{REFERENCES}

Almasi, J. F., McKeown, M. G., \& Beck, I. L. (1996). The nature of engaged reading in classroom discussions of $\begin{array}{llll}\text { literature. Journal of Literacy } & \text { 107-146. }\end{array}$ https://journals.sagepub.com/doi/pdf/10.1080/10862969609547913

Almasi, J. F., Palmer, B. M., Garas, K., Cho, H., Ma, W., Sanan, L., \& Augustino, A. (2004, April). A longitudinal investigation of the influence of peer discussion of text on reading development in grades K-3. Field initiated studies program report. Office of Educational Research and Improvement.

Alper, L. (1996). Problem-Based Mathematics--Not Just for the College-Bound. Educational Leadership, 53(8), 18-21.

Ames, C., \& Archer, J. (1988). Achievement goals in the classroom: Students' learning strategies and motivation processes. Journal of Educational Psychology, 80(3), 260. https://doi.org/10.1037/00220663.80.3.260

Bandura, A. (1977). Self-efficacy: toward a unifying theory of behavioral change. Psychological Review, 84(2), 191. https://doi.org/10.1037/0033-295X.84.2.191

Bednar, A., Cunningham, D., Duffy, T., \& Perry, J. (1992). Theory into practice: How do we link? In T. Duffy and D. Jonassen (Eds.), Constructivism and the Technology of Instruction: A Conversation. Lawrence Erlbaum.

Bereiter, C., \& Scardamalia, M. (2006). Education for the Knowledge Age: Design-Centered Models of Teaching and Instruction.

Biggs, J. (1999). What the student does: Teaching for enhanced learning. Higher Education Research \& Development, 18(1), 57-75. https://doi.org/10.1080/0729436990180105

Bolman, L. G., \& Deal, T. E. (2013). Artistry, choice, \& leadership: Reframing organizations.

Bond, T. (2001). Giving them free rein: Connections in student-led book groups. The Reading Teacher, 54(6), 574-584.

Bonk, C. J., \& Cunningham, D. J. (1998). Searching for learner-centered, constructivist, and sociocultural components of collaborative educational learning tools. In C. J. Bonk \& K. S. King (Eds.), Electronic Collaborators: Learner-Centered Technologies for Literacy, Apprenticeship, and Discourse (pp. 25-50). Lawrence Erlbaum.

Boyle, J. T., \& Nicol, D. J. (2003). Using classroom communication systems to support interaction and discussion in large class settings. ALT-J, 11(3), 43-57. https://doi.org/10.3402/rlt.v11i3.11284 
Bridges, D. (1988). Education, democracy, and discussion. University Press of America.

Brower, H. H. (2003). On emulating classroom discussion in a distance-delivered OBHR course: Creating an on-line learning community. Academy of Management Learning \& Education, 2(1), 22-36. https://doi.org/10.5465/amle.2003.9324013

Brown, J. S., Collins, A., \& Duguid, P. (1989). Situated cognition and the culture of learning. Educational Researcher, 18(1), 32-42. https://journals.sagepub.com/doi/pdf/10.3102/0013189X018001032

Brush, T., \& Saye, J. (2000). Implementation and evaluation of a student-centered learning unit: A case study. Educational Technology Research and Development, 48(3), 79-100. https://doi.org/10.1007/BF02319859

Byers, T., Imms, W., \& Hartnell-Young, E. (2014). Making the case for space: The effect of learning spaces on teaching and learning. Curriculum and Teaching, 29(1), 5-19. https://doi.org/10.7459/ct/29.1.02

ChanLin, L. J. (2017). Analysis of Teachers' Tablet Teaching Adoption Process. Educational Sciences: Theory \& Practice, 17(6), 1935-1958. https://doi.org/10.12738/estp.2017.6.0436

Cheng, C. K., Paré, D. E., Collimore, L.-M., \& Joordens, S. (2011). Assessing the effectiveness of a voluntary online discussion forum on improving students' course performance. Computers \& Education, 56(1), 253-261. https://doi.org/10.1016/j.compedu.2010.07.024

Cheng, Y. C., \& Yeh, H. T. (2009). From concepts of motivation to its application in instructional design: Reconsidering motivation from an instructional design perspective. British Journal of Educational Technology, 40(4), 597-605. https://doi.org/10.1111/j.1467-8535.2008.00857.x

Chiu, T. K., \& Churchill, D. (2016). Adoption of mobile devices in teaching: changes in teacher beliefs, attitudes and anxiety. Interactive Learning Environments, 24(2), 317-327. https://doi.org/10.1080/10494820.2015.1113709

Conley, D. T., \& French, E. M. (2014). Student ownership of learning as a key component of college readiness. American Behavioral Scientist, 58(8), 1018-1034. https://doi.org/10.1177/0002764213515232

Cowie, B., \& Bell, B. (1999). A model of formative assessment in science education. Assessment in Education: Principles, Policy \& Practice, 6(1), 101-116. https://doi.org/10.1080/09695949993026

Davis, G. A. (1989). Objectives and Activities for Teaching Creative Thinking 1. Gifted Child Quarterly, 33(2), 81-84. https://doi.org/10.1177/001698628903300208

Dovros, N., \& Makrakis, V. (2012). Transforming the classroom into a reflective community: A blended learning instructional approach. Journal of Teacher Education for Sustainability, 14(2), 73-88. https://doi.org/10.2478/v10099-012-0010-z

Doyle, T. (2008). Helping students learn in a learner-centered environment: A guide to facilitating learning in higher education. Stylus Publishing: LLC.

Duffy, T. M., \& Jonassen, D. H. (1992). Constructivism: New implications for instructional technology. Constructivism and the technology of instruction: A conversation. Lawrence Erlbaum Associates, Inc.

Eliason, S., \& Holmes, C. L. (2012). A course redesign project to change faculty orientation toward teaching. Journal of the Scholarship of Teaching and Learning, 12(1), 36-48.

Ferreira, M. J. M. (2012). Intelligent classrooms and smart software: Teaching and learning in today's university. Education and Information Technologies, 17(1), 3-25. https://doi.org/10.1007/s10639-0109134-8

Fies, C., \& Marshall, J. (2006). Classroom response systems: A review of the literature. Journal of Science Education and Technology, 15(1), 101-109. https://doi.org/10.1007/s10956-006-0360-1 
Froyd, J., \& Simpson, N. (2008, August). Student-centered learning addressing faculty questions about student centered learning. In Course, Curriculum, Labor, and Improvement Conference, Washington DC (Vol. 30, No. 11, pp. 1-11).

Gallagher, S. A., \& Stepien, W. J. (1996). Content acquisition in problem-based learning: Depth versus breadth in American studies. Talents and Gifts, 19(3), 257-275. https://doi.org/10.1177/016235329601900302

Hagenson, L., \& Castle, K. (2003). The integration of technology into teaching by university college of education faculty. In Society for Information Technology \& Teacher Education International Conference (pp. 947-952). Association for the Advancement of Computing in Education (AACE).

Hannafin, M. J., \& Land, S. M. (1997). The foundations and assumptions of technology-enhanced studentcentered learning environments. Instructional Science, 25(3), 167-202. https://doi.org/10.1023/A:1002997414652

Hannafin, M. J., Hill, J. R., Land, S. M., \& Lee, E. (2014). Student-centered, open learning environments: Research, theory, and practice. In M. Spector, M. D. Merrill, J. Van Merrienboer, \& M. P. Driscoll (Eds.), Handbook of Research on Educational Communications and Technology (pp. 641-651). Springer. https://doi.org/10.1007/978-1-4614-3185-5_51

Hannafin, M., Hannafin, K., \& Gabbitas, B. (2009). Re-examining cognition during student-centered, Webbased learning. Educational Technology Research and Development, 57(6), 767-785. https://doi.org/10.1007/s11423-009-9117-x

Hannafin, M., Land, S., \& Oliver, K. (1999). Open learning environments: Foundations, methods, and models. In C. M. Reigeluth (Ed.), Instructional-design theories and models: A new paradigm of instructional theory (vol. 2, pp. 115-140). Lawrence Erlbaum Associates.

Hannafin, R. D., \& Foshay, W. R. (2008). Computer-based instruction's (CBI) rediscovered role in K-12: An evaluation case study of one high school's use of CBI to improve pass rates on high-stakes tests. Educational Technology Research and Development, 56(2), 147-160. https://doi.org/10.1007/s11423006-9007-4

Hawe, E. (2007). Student teachers' discourse on assessment: Form and substance. Teaching in Higher Education, 12(3), 323-335. https://doi.org/10.1080/13562510701278666

Hulan, N. (2010). What the Students Will Say While the Teacher is Away: An Investigation into Student-Led and Teacher-Led Discussion Within Guided Reading Groups. Literacy Teaching and Learning, 14, 4164.

Insorio, A. O. (2021). Technological and operational mobile learning readiness of secondary teachers. International Journal of Pedagogical Development and Lifelong Learning, 2(1), ep2103. http://doi.org?10.30935/ijpdll/9362

Jonassen, D. H. (1992). Evaluating constructivist learning. In T. M. Duffy \& D. H. Jonassen (Eds.), Constructivism and the technology of instruction: A conversation (pp. 137-148). Routledge.

Kavanagh, M. H., \& Ashkanasy, N. M. (2006). The impact of leadership and change management strategy on organizational culture and individual acceptance of change during a merger. British journal of management, 17(S1), S81-S103. https://doi.org/10.1111/j.1467-8551.2006.00480.x

Keefer, M. W., Zeitz, C. M., \& Resnick, L. B. (2000). Judging the quality of peer-led student dialogues. Cognition and Instruction, 18(1), 53-81. https://doi.org/10.1207/S1532690XCI1801_03

Keengwe, J., Kidd, T., \& Kyei-Blankson, L. (2009). Faculty and Technology: Implications for Faculty Training and Technology Leadership. Journal of Science Education \& Technology, 18(1), 23-28. https://doi.org/10.1007/s10956-008-9126-2 
Kozma, R. B. (2003). Technology and classroom practices: An international study. Journal of Research on Technology in Education, 36(1), 1-14. https://doi.org/10.1080/15391523.2003.10782399

Kulasegaram, K., \& Rangachari, P. K. (2018). Beyond "formative": assessments to enrich student learning. Advances in Physiology Education, 42(1), 5-14. https://doi.org/10.1152/advan.00122.2017

Lai, Y. H. (2019). The Application of Meta-Analytic SEM on Exploring Factors That Influence Teachers' Usage of Interactive Whiteboard. Pedagogical Research, 4(3), em0038. https://doi.org/10.29333/pr/5854

Leal, D. (1993). The power of literary peer-group discussions: How children collaboratively negotiate meaning. The Reading Teacher, 47(2), 114-120.

Lee, E., \& Hannafin, M. J. (2016). A design framework for enhancing engagement in student-centered learning: Own it, learn it, and share it. Educational Technology Research and Development, 64(4), 707734. https://doi.org/10.1007/s11423-015-9422-5

Lee, W., \& Reeve, J. (2012). Teachers' estimates of their students' motivation and engagement: Being in synch $\begin{array}{llll}\text { with } \quad \text { students. } & \text { 727-747. }\end{array}$ https://doi.org/10.1080/01443410.2012.732385

Lee, Y. H., Waxman, H., Wu, J. Y., Michko, G., \& Lin, G. (2013). Revisit the effect of teaching and learning with technology. Journal of Educational Technology \& Society, 16(1), 133-146.

Macfadyen, L. P., \& Dawson, S. (2012). Numbers are not enough. Why e-learning analytics failed to inform an institutional strategic plan. Journal of Educational Technology \& Society, 15(3), 149-163.

Maloch, B. (1999). Shifting to Student-Centered, Collaborative Classrooms: Implementing Student-Led Discussion Groups [Paper presentation]. Annual Meeting of the American Educational Research Association, Montreal, Quebec, Canada, April 19-23.

McWilliam, E., Sweet, C., \& Blythe, H. (2013). Re/membering pedagogical spaces. In Cases on higher education spaces: Innovation, collaboration, and technology (pp. 1-13). IGI Global. https://doi.org/10.4018/978-1-4666-2673-7.ch001

Means, B. (1994). Introduction: Using technology to advance educational goals. In B. Means (Ed.), Technology and education reform: The reality behind the promise. San Francisco: Jossey-Bass.

Mergendoller, J. R., Maxwell, N. L., \& Bellisimo, Y. (2006). The effectiveness of problem-based instruction: A comparative study of instructional methods and student characteristics. Interdisciplinary Journal of Problem-based Learning, 1(2), 49-69. https://doi.org/10.7771/1541-5015.1026

Mishra, P., \& Koehler, M. J. (2006). Technological pedagogical content knowledge: A framework for teacher knowledge. Teachers College Record, 108(6), 1017-1054. https://doi.org/10.1111/j.14679620.2006.00684.x

Moats, J. (2015). Influences on the acceptance of innovative technologies used in learning opportunities: A theoretical perspective. In Handbook of research on innovative technology integration in higher education (pp. 262-281). IGI Global. https://doi.org/10.4018/978-1-4666-8170-5.ch013

Mueller, J., Wood, E., Willoughby, T., Ross, C., \& Specht, J. (2008). Identifying discriminating variables between teachers who fully integrate computers and teachers with limited integration. Computers \& Education, 51(4), 1523-1537. https://doi.org/10.1016/j.compedu.2008.02.003

Nichols, S. L., \& Dawson, H. S. (2012). Assessment as a context for student engagement. In Handbook of research on student engagement (pp. 457-477). Springer. https://doi.org/10.1007/978-1-4614-20187_22 
Nicol, D. J., \& Macfarlane-Dick, D. (2006). Formative assessment and self-regulated learning: A model and seven principles of good feedback practice. Studies in Higher Education, 31(2), 199-218. https://doi.org/10.1080/03075070600572090

Nordquist, J., \& Laing, A. (2015). Designing spaces for the networked learning landscape. Medical Teacher, 37(4), 337-343. https://doi.org/10.3109/0142159X.2014.1001349

Onurkan Aliusta, Gülen, \& Özer, Bekir. (2017). Student-centred learning (SCL): Roles changed? Teachers and Teaching, Theory and Practice, 23(4), 422-435.

Paavola, S., \& Hakkarainen, K. (2009, June). From meaning making to joint construction of knowledge practices and artefacts: a trialogical approach to CSCL. In CSCL (1) (pp. 83-92).

Ross, J. A., Hogaboam-Gray, A., \& Hannay, L. (2001). Effects of Teacher Efficacy on Computer Skills and Computer Cognitions of Canadian Students in Grades K-3. The Elementary School Journal., 102(2), 141156. https://doi.org/10.1086/499697

Sadler, D. R. (1998). Formative assessment: Revisiting the territory. Assessment in education: principles, policy \& practice, 5(1), 77-84. https://doi.org/10.1080/0969595980050104

Salas-Rueda, R. A. (2018). Analysis on the Use of Continuous Improvement, Technology and Flipped Classroom in the Teaching-Learning Process by means of Data Science. Online Journal of Communication and Media Technologies, 8(4), 325-343. https://doi.org/10.12973/ojcmt/3955

Seminoff, N. E., \& Wepner, S. B. (1997). What should we know about technology-based projects for tenure and promotion? Journal of Research on Computing in Education, 30(1), 67-82. https://doi.org/10.1080/08886504.1997.10782214

Vygotsky, L. S. (1978). Mind in society: The development of higher psychological processes. Harvard University Press.

Vygotsky, L. S. (1980). Mind in society: The development of higher psychological processes. Harvard University Press. https://doi.org/10.2307/j.ctvjf9vz4

Wigfield, A., \& Eccles, J. S. (2002). The development of competence beliefs, expectancies for success, and achievement values from childhood through adolescence. In Development of Achievement Motivation (pp. 91-120). Academic Press. https://doi.org/10.1016/B978-012750053-9/50006-1

Wood, E., Mueller, J., Willoughby, T., Specht, J., \& Deyoung, T. (2005). Teachers' perceptions: Barriers and supports to using technology in the classroom. Education, Communication \& Information, 5(2), 183206. https://doi.org/10.1080/14636310500186214

Worthy, J., \& Beck, I. (1995). On the road from recitation to discussion in large-group dialogue about literature. In K. Hinchman, D. Leu, \& C. Kinzer (Eds), Perspectives on Literacy Research and Practice: Forty fourth Yearbook of the National Reading Conference. NRC.

Yim, J. S. C., Moses, P., \& Azalea, A. (2018). Effects of psychological ownership on teachers' beliefs about a cloud-based virtual learning environment. Research and Practice in Technology Enhanced Learning, 13(1), 13. https://doi.org/10.1186/s41039-018-0081-0

Zimmerman, B. J., Bandura, A., \& Martinez-Pons, M. (1992). Self-motivation for academic attainment: The role of self-efficacy beliefs and personal goal setting. American Educational Research Journal, 29(3), 663-676. https://doi.org/10.3102/00028312029003663

Correspondence: Trang Phan, California State University Fresno, Fresno, CA, USA.

E-mail: tphan@mail.fresnostate.edu 